\title{
Yield and N Uptake by Seven Perennial Grass Species as Affected by High Rates of N Ferti- lizer
}

\author{
L.E. LUTWICK AND A.D. SMITH
}

\begin{abstract}
Seven species of grass were grown on plots to which $\mathbf{N}$ had been applied at progressively increasing rates (0 to $775 \mathrm{~kg} \mathrm{~N} / \mathrm{ha}$ ) to reach and exceed those required for maximum yields. Yield of hay and protein in all seven grasses increased with $\mathbf{N}$ fertilizer. Recoveries of $\mathrm{N}$ were only 12 to $31 \%$ when applied once, and 8 to $14 \%$ when applied every year. Because these recoveries are considered to be uneconomical, massive rates of $\mathbf{N}$ fertilizer are not recommended. Intermediate wheatgrass produced the most hay and protein. All seven grasses responded most to applied $\mathbf{N}$ in the first 2 years after application, regardless of age of stand.
\end{abstract}

Cultivated grasses are assuming greater importance in the dryland culture of the semiarid plains. Grasses are being grown for short-term use in rotation with grains to improve structure and to allow a buildup of organic matter and $\mathrm{N}$ in the soil. Also, cattle are being finished with less grain; thus greater quantities of perennial hay as well as permanent pasture are required. In these situations, $\mathrm{N}$ fertilizer would be expected to enhance yield and protein content.

Many studies concerning the response of grasses to $\mathrm{N}$ fertilizer have been restricted to a single species (Lorenz and Rogler 1962; Mason and Miltimore 1972; Sneva 1973). However, Heinricks and Clark (1961) found that five species of grass all responded to $\mathrm{N}$ fertilizer although they differed in their efficiencies of $\mathrm{N}$ use. Old stands of crested wheatgrass (CWG) increased production with $\mathrm{N}$ fertilizer if soil moisture was adequate during the growing season (Seamands and Lang 1960). Kilcher (1958) found that $N$ fertilization of CWG was economical in most years. For Russian wildrye (RWR), fertilization was economical only in the first 2 moist years and, for intermediate wheatgrass (IWG), it was economical in only the first wet year. Smika et al. (1960) reported that bromegrass, CWG, and RWR were inefficient users of fertilizer $\mathrm{N}$ and that recovery of $\mathrm{N}$ increased in cooler years.

The objective of this study was to determine those grass species that would respond most efficiently to applications of high rates of $\mathrm{N}$ fertilizer.

\section{Materials and Methods}

The soil of the experimental site at the Agriculture Canada Research Station, Lethbridge, Alta., was a Lethbridge loam (Typic Haploboroll, Orthic Dark Brown Chernozemic soil developed on alluviallacustrine parent material) previously cropped in a grain-fallow rotation. Before the study was started, triple superphosphate (0-45-0 at $67 \mathrm{~kg} \mathrm{P} / \mathrm{ha}$ ) was broadcast uniformly over the experimental area. A

Authors are soil scientist and agronomist (retired), respectively, Research Station $\Lambda$ griculture Canada, Lethbridge, Albcrta, T1 J 4B1.

Manuscript received August 31, 1978. randomized block design with four replicates was used. Each plot consisted of 12 rows of a single species seeded in rows $20 \mathrm{~cm}$ apart and $40 \mathrm{~m}$ long in the spring of 1965. Seven grasses were seeded: intermediate wheatgrass (IWG, Agropyron intermedium (Host) Beauv.); Russian wildrye (RWR, Elymus junceus Fisch.); streambank wheatgrass (SWG, A. riparium Scribn. and Smith); crested wheatgrass (CWG, A. cristatum (L.) Gaertn. cv Fairway); timothy (TIM, Phleum pratense L. cv Climax); western wheatgrass (WWG, A. smithii Rydb.); and bromegrass (BRG, Bromus inermis Leyss.). Unless otherwise stated, the crops seeded were commercial grade.

In early spring of each of 3 consecutive years, single applications of ammonium nitrate (34-0-0) were broadcast on the appropriate blocks as a means of evaluating the effect of age of stand. The fertilizer was applied once with an increasing-rate spreader (Lutwick et al. 1965) along each grass plot at rates from 0 to $775 \mathrm{~kg} \mathrm{~N} / \mathrm{ha}$. Plots 1 to 28 were fertilized in 1966, 29 to 56 in 1967, and 57 to 84 in 1968. As an adjunct to the experiment, plots 85 to 112 were fertilized at the same rates of $\mathrm{N}$ in $1967,1968,1969$, and 1970 to allow evaluation of the effect of applying fertilizer every year. Yield measurements were taken each year from 1966 to 1970, except that some plots of TIM were not harvested in 1970 because of excessive weed growth.

All forages were harvested when CWG reached the seed-set stage. The center four rows of each $40-\mathrm{m}$ strip were cut for yield beginning at $2 \mathrm{~m}$ and then at every $4 \mathrm{~m}$ along the strip. Each of these points was the center of an $80-\mathrm{cm}$ length and they were located where the rates of $\mathrm{N}$ application were $0,28,76,165,254,354,465,572,671$, and $744 \mathrm{~kg}$ $\mathrm{N} / \mathrm{ha}$. The harvested area was $80 \mathrm{~cm} \times 80 \mathrm{~cm}$. The forage samples were dried in a forced-draft oven at $60^{\circ} \mathrm{C}$. Samples collected at 0,165 , 465 , and $744 \mathrm{~kg} \mathrm{~N} / \mathrm{ha}$ rates were analyzed for total N (protein) content by the Kjeldahl-Wilfarth-Gunning method (Association of Official Agricultural Chemists 1950) after grinding in a Wiley mill to pass a 1-mm sieve.

All yield and $\mathrm{N}$ content data, within species and year of harvest, were fitted to regression curves of the form $\hat{y}=a+b X+c X /$ where $\hat{y}$ is the estimated yield (kg/ha) or estimated $\mathrm{N}$ content (\%) and $X$ is the fertilizer rate $(\mathrm{kg} / \mathrm{ha})$. There were 111 equations for yield and 111 for total $\mathrm{N}$ content. Of these, only 21 correlation coefficients were not significant $(P<0.05)$ and they occurred mainly in the fourth and fifth years after fertilizing. $\mathrm{N}$ content data are not reported but were used to calculate $\mathrm{N}$ uptake (yield $\times \mathrm{N}$ content).

Comparisons were made with derived data; thus, intercepts were taken as yield without $\mathrm{N}$ fertilizer $\left(\mathrm{N}_{o}\right)$ and the first derivative of the equation allowed calculation of the rate of $\mathrm{N}$ applied at maximum yield $\left(\mathrm{N}_{m}\right)$. Yields and $\mathrm{N}$ uptake for the successive years at $\mathrm{N}_{m}$ and $\mathrm{N}_{o}$ in the year of application are reported. With these data, the species should show their relative and maximum capabilities for growth under the climatic conditions that occurred at the experimental site.

Metcorological data were collected about $1.5 \mathrm{~km}$ from the plot area. Comparatively, 1966 and 1967 were the wettest years and 1968 and 1970 were the driest, based on the moisture deficit calculated as the difference between evaporation and precipitation for May and June (Table 1). Also, weather in 1967 was relatively cool especially in April, when high precipitation was received. 
Table 1. Weather data collected about $1.5 \mathrm{~km}$ from plot site.

\begin{tabular}{|c|c|c|c|c|c|}
\hline Year & April & May & June & July & $\begin{array}{c}\text { Seasonal } \\
\text { mean or } \\
\text { total* }\end{array}$ \\
\hline & \multicolumn{5}{|c|}{ Mean temperature $\left({ }^{\circ} \mathrm{C}\right)$} \\
\hline 1965 & 5.3 & 10.1 & 13.8 & 18.5 & 11.93 \\
\hline 1966 & 3.7 & 11.4 & 14.1 & 17.2 & 11.60 \\
\hline 1967 & -0.7 & 8.4 & 14.0 & 19.0 & 10.18 \\
\hline 1968 & 4.1 & 9.3 & 14.4 & 17.2 & 11.25 \\
\hline 1969 & 8.5 & 12.1 & 14.3 & 16.9 & 12.95 \\
\hline \multirow[t]{2}{*}{1970} & 3.8 & 11.7 & 18.0 & 19.9 & 13.35 \\
\hline & \multicolumn{5}{|c|}{ Precipitation (mm) } \\
\hline 1965 & 31.24 & 47.75 & 147.07 & 57.15 & 283.21 \\
\hline 1966 & 38.35 & 62.74 & 121.92 & 95.25 & 318.26 \\
\hline 1967 & 112.52 & 57.15 & 81.53 & 1.52 & 252.72 \\
\hline 1968 & 40.39 & 42.93 & 70.10 & 18.29 & 171.71 \\
\hline 1969 & 13.97 & 32.00 & 127.25 & 34.29 & 207.51 \\
\hline \multirow[t]{2}{*}{1970} & 30.23 & 32.77 & 86.61 & 16.00 & 165.61 \\
\hline & \multicolumn{5}{|c|}{ Evaporation (mm) } \\
\hline 1965 & - & 133.35 & 144.27 & 168.40 & 446.02 \\
\hline 1966 & - & 169.67 & 158.24 & 200.41 & 528.32 \\
\hline 1967 & - & 96.27 & 159.26 & 285.75 & 541.28 \\
\hline 1968 & 108.97 & 182.88 & 222.25 & 241.05 & 646.18 \\
\hline 1969 & 168.66 & 222.00 & 169.42 & 245.11 & 636.53 \\
\hline 1970 & 143.51 & 219.96 & 247.90 & 278.13 & 745.99 \\
\hline
\end{tabular}

* Mean for temperatures, seasonal total for precipitation. and May-July total for evaporation.

\section{Results}

\section{Invaders or Invaded}

Since all seven species were seeded in relatively narrow, randomized, contiguous strips, neighbours could readily demonstrate aggressiveness, passivity, or resistance towards each other in terms of invasion. Only the strips seeded to RWR, CWG, SWG, and BRG remained in pure stands throughout the study. The other three species were invaded by neighbouring species or weeds. In the third or fourth year after seeding, the stands of TIM, IWG, and WWG were much reduced.

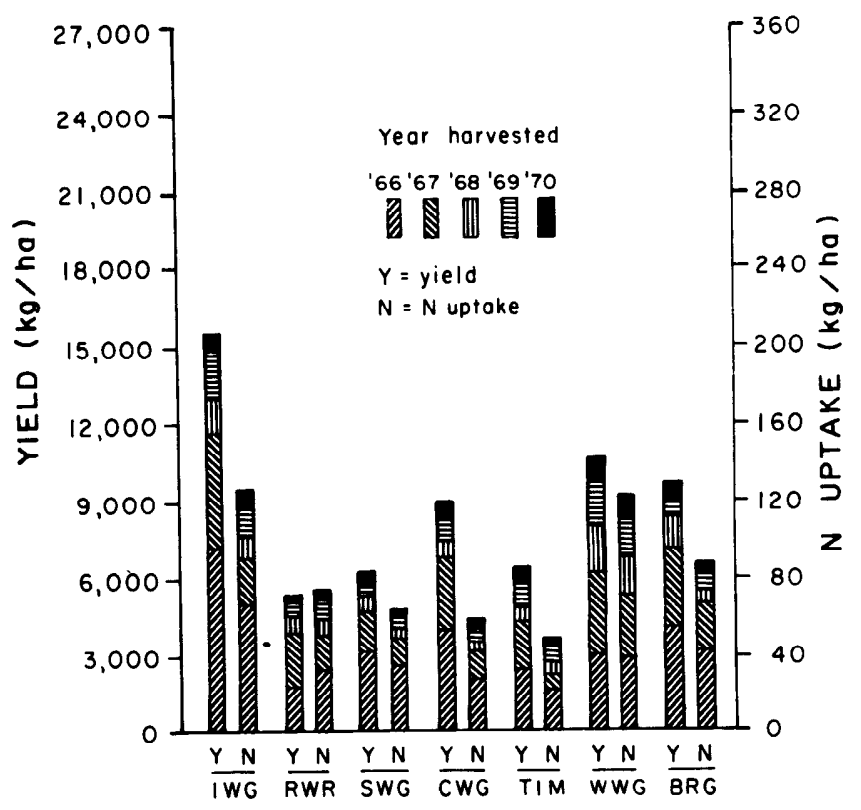

Fig. 1. Cumulative yield and $N$ uptake of seven grasses grown without $N$ fertilizer.
RWR did not invade other species but maintained sharp boundaries. CWG was the most aggressive invader and appeared throughout the plots of the invaded species. SWG, WWG, and BRG invaded other species along the plot edges.

At high rates of N, TIM was killed out and the plots then became especially vulnerable to invasion by weeds. The stand densities of the other species were not noticeably affected by high rates of $\mathrm{N}$.

In view of these comments, only RWR, SWG, CWG, and BRG should be considered as pure species for the full course of the study. However, WWG, IWG, and TIM can be considered as pure stands for the first 3 or 4 years after seeding. Nonetheless, data are presented for all plots according to the species in the original seeding.

\section{Yield and Uptake without $\mathbf{N}$ Fertilizer}

Highest unfertilized yields, accumulated over the 5 years of the study, were produced by IWG followed in order by WWG, BRG, and CWG; the other three species produced equal low yields (Fig. 1). For all seven grasses, yields were substantially larger in the first and second crop years than in the subsequent 3 years. This difference may be attributable to relatively wet seasons in the first 2 years of cropping (Table 1). However, IWG and WWG continued to produce highest yields in the last 3 , somewhat drier, years.

Total $\mathrm{N}$ uptake (yield $\times \mathrm{N}$ content), and hence total protein produced per hectare, generally followed the same pattern as yields (Fig. 1). Thus, most protein was produced by those grasses that produced the highest yields, greatest amounts were produced in the first 2 years, and markedly lower amounts were produced in the last 3 years. CWG, although one of the high yielders, produced a small amount of protein.

\section{Yield and N Uptake with N Fertilizer Applied Once}

The amounts of fertilizer $\mathrm{N}\left(\mathrm{N}_{m}\right)$ required to produce maximum yields $\left(\mathrm{Y}_{m}\right)$ were calculated from the regression equations for each grass for each of the 3 years of application (Table 2). Generally, the highest value of $\mathrm{N}_{m}$ occurred in the driest year (1968) and the lowest in the wettest year (1967). Also, the difference between the highest and lowest species was greatest in the driest year and least in the wettest year. The amounts required for RWR and BRG varied the most among years; those required for CWG, TIM, and WWG varied the least among years.

Table 2. N (kg/ha) applied at maximum yields calculated from regression equations.

\begin{tabular}{lccc}
\hline \hline Grass & 1966 & 1967 & 1968 \\
\hline IWG & 441 & 455 & 581 \\
RWR & 510 & 475 & 858 \\
SWG & 548 & 494 & 678 \\
CWG & 575 & 481 & 572 \\
TIM & 459 & 450 & 543 \\
WWG & 593 & 506 & 581 \\
BRG & 484 & 439 & 758 \\
\hline
\end{tabular}

The values for $\mathrm{N}_{m}$, determined for each year of application and for each grass species, were substituted into the yield and $\mathrm{N}$ content equations determined for the first and subsequent ycars. In general, highest yields were obtained in the year of application with a considerable carry-over effect in the second year and somewhat less in the third year (Fig. 2). In most cases, the yields in 1968 , when $\mathrm{N}_{m}$ was highest, were lower than the 


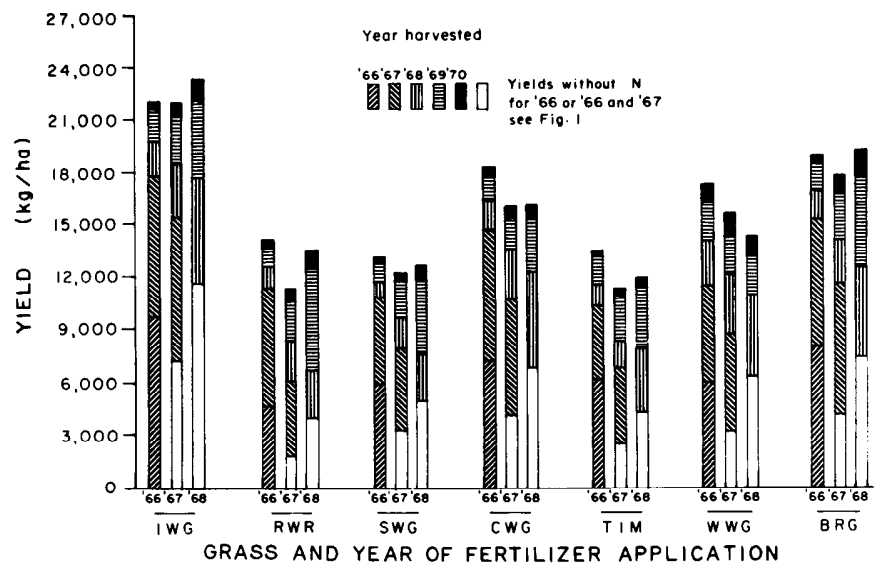

Fig. 2. Cumulative yield of seven grasses grown with $N$ fertilizer applied once.

yields obtained in either 1966 or 1967 from fertilizers applied in those years.

The carry-over effect of spring-applied fertilizer $\mathrm{N}$ was inversely related to the moisture supply in the year of application; thus, for the grasses fertilized in 1967, which had a high rainfall in April (Table 1), the second crop yields (1968) were much lower than the second year yields after fertilizer was applied in 1966 and 1968.

For each grass, the total yields over the 5 years were similar regardless of when the fertilizer was applied. Thus, age of stand of grass had no particular effect upon response to $\mathrm{N}$ fertilizer.

IWG produced the highest yields; CWG, WWG, and BRG produced similar intermediate yields; and RWR, SWG, and TIM produced similar lowest yields (Fig. 2).

With the exception of two cases, RWR and SWG fertilized in 1968, the greatest uptake of $\mathrm{N}$ for all grasses occurred in the year the fertilizer was applied (Fig. 3). For most of the species, the total uptake of $\mathrm{N}$, or harvestable protein, was similar for the 5 years regardless of year of fertilizer application. However, RWR produced more protein when fertilized in 1968, and CWG and WWG produced less, than when fertilized in 1966 or 1967.

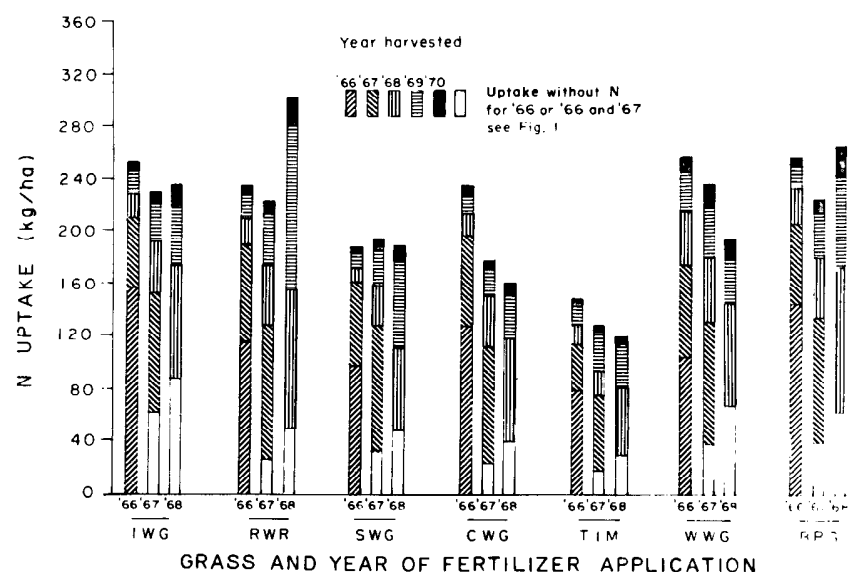

Fig. 3. Cumulative uptake of $N$ by seven grasses grown with $N$ fertilizer applied once.

With these noted exceptions, IWG, RWR, WWG, and BRG produced the most protein and TIM produced the least.

Yield and N Uptake with $N$ Fertilizer Applied Every Year Where $N_{m}$ was applied every year, 1967 to 1970 , yields of the

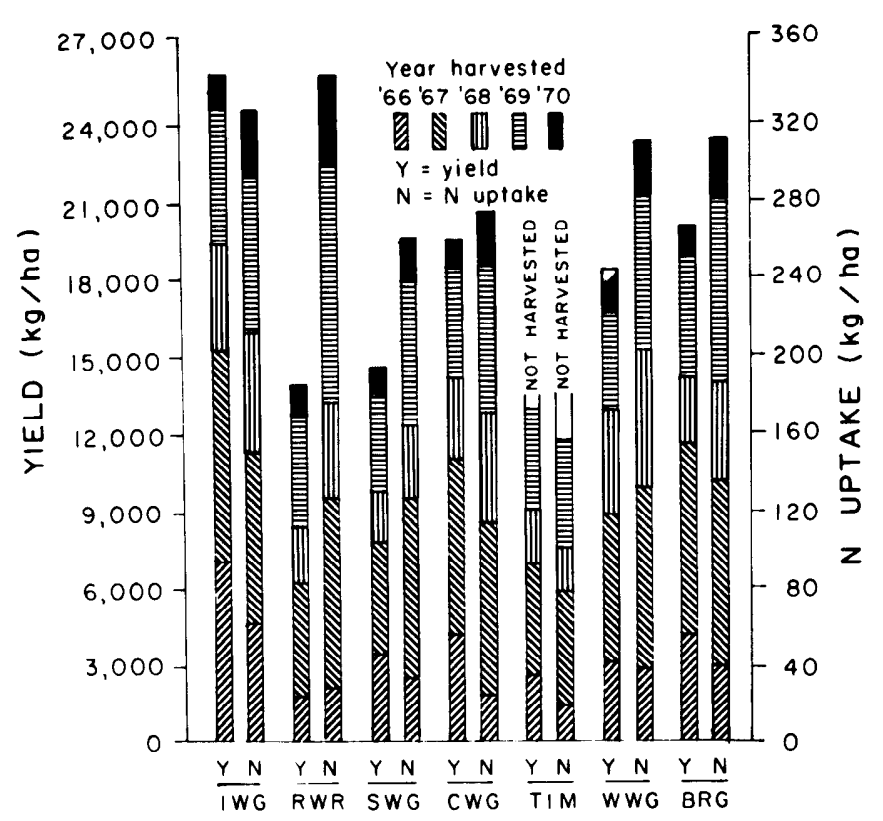

Fig. 4. Cumulative yield and $N$ uptake of seven grasses grown with $N$ fertilizer applied every year, 1967-1970.

grasses were only slightly greater than where applied once (Figs. 4 and 2). Uptake of $\mathrm{N}$, however, was, in most cases, substantially greater (Figs. 3 and 4). Nonetheless, the differences among species were similar with both methods of applying $\mathbf{N}$ fertilizer.

With the $\mathrm{N}$ applied every year, the effects of available moisture on yield and $\mathrm{N}$ uptake were readily apparent and were not confounded with possible differences in $\mathrm{N}$ availability. Thus, yields and $N$ uptake were greatest in 1967 and 1969, the wet years, and least in 1970, the driest year.

\section{Recovery of Applied N}

The fraction of fertilizer $\mathrm{N}$ used by the grasses was calculated as net uptake $\left(U N_{m}-U N_{o}\right)$ per unit of $\mathrm{N}$ applied. With $\mathrm{N}$ fertilizer applied once and with the exception of RWR and SWG fertilized in 1968, the greatest percentage of fertilizer use occurred in the year of application (Fig. 5). Recoveries were distinctly greater in the first and second than in subsequent years. However, only 12 to $30 \%$ of the applied $\mathrm{N}$ was recovered in the crops harvested in the first 2 years.

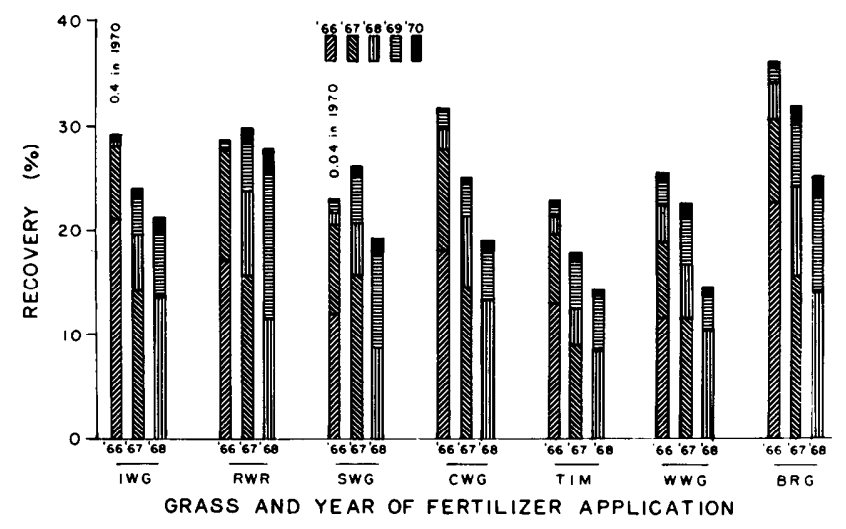

Fig. 5. Percentage recovery of $N$ from fertilizer applied once. 
In general, the first year fractional recoveries of fertilizer $\mathbf{N}$ decreased with age of stand (Fig. 5). This could not be credited to increasing drought, since the recovery of $\mathrm{N}$ applied in 1968, a dry year, was actually only slightly less than that of 1967 , a year of good rainfall in April. With two exceptions, SWG and WWG, the recoveries of 1966 were much greater than that for the other 2 years. It seems more likely that the abilities of the grasses to recover $\mathrm{N}$ fertilizer decreases with age of stand. However, age of stand seems to affect some grasses more than others. Thus, the difference between high recovery in 1966 and low recovery in 1968 was small for WWG $(1.3 \%)$ and large for BRG $(8.1 \%)$ and IWG $(7.5 \%)$.

Where fertilizer was applied every year, fractional recoveries of $\mathrm{N}$ for each year were calculated by accumulating net yearly uptakes $\left(U N_{m}-U N_{o}\right)$ and dividing by accumulated applications of fertilizer $\left(\mathrm{N}_{m}, 2 \mathrm{~N}_{m}, 3 \mathrm{~N}_{m}, 4 \mathrm{~N}_{m}\right)$ (Table 3 ). This method of calculation was used because effects of residual $\mathrm{N}$ could not be separated from the direct effect of the application in the current year. The recoveries for all 4 years ( 8 to $14 \%$ in 1970) were slightly less than those of the first year ( 9 to $16 \%$ in 1970) (Table 3 ) and much less than the total recoveries in 4 years after one application (18 to $31 \%$ for 1967 to 1970) (Fig. 5).

Table 3. Percentage* recovery of $\mathbf{N}$ from plots receiving $\mathbf{N}$ every year.

\begin{tabular}{lrrrc}
\hline \hline Grass & 1967 & 1968 & 1969 & 1970 \\
\hline IWG & 14.1 & 12.2 & 12.7 & 10.6 \\
RWR & 15.7 & 12.6 & 16.6 & 14.0 \\
SWG & 15.7 & 10.8 & 11.9 & 9.7 \\
CWG & 14.3 & 12.4 & 12.8 & 10.8 \\
TIM & 8.9 & 6.7 & 7.4 & - \\
WWG & 11.4 & 10.2 & 10.1 & 8.3 \\
BRG & 15.5 & 12.7 & 14.4 & 12.2 \\
\hline
\end{tabular}

* Since residual effects could not be separated from effect of currently applied $\mathrm{N}$, net uptakes were accumulated for successive years and divided by total amount of $\mathrm{N}$ applied up to and including the year indicated.

Whether applied once or every year, recoveries of fertilizer $\mathbf{N}$ by TIM and WWG were low, but differences among the other species were small (Fig. 5, Table 3).

\section{Discussion}

In choosing a grass species for use in the Dark Brown Soil Zone, at least two situations should be differentiated: short-term use, such as in rotation with grains, and long-term use, such as permanent hay or pasture. In short-term use, persistence of the stand or resistance to invasion by other species would not be as important as quantity of hay production and efficiency of the grass to use $\mathrm{N}$ fertilizer. In these respects, IWG produced the most hay and had the greatest uptake of $\mathrm{N}$ (protein production), especially in the first 2 years after establishment, with or without $\mathrm{N}$ fertilizer. In the dry years, IWG and WWG produced more hay and protein than the other five species. These would seem to be the species of choice for short-term use; in long-term use, their ability to maintain their stands may be a limitation.

For long-term use, CWG and BRG maintained pure stands and produced relatively high yields with or without $\mathrm{N}$ fertilizer. Protein production by BRG was much higher than that of CWG and was more easily increased with $\mathrm{N}$ fertilizer. $\mathrm{RWR}$ required $\mathrm{N}$ fertilizer to produce yield and protein in quantities comparable to those of BRG.

All seven species of grasses used in this study responded to $\mathrm{N}$ fertilizer, both in terms of increased yields and increased protein production. However, the effects of the applied $\mathrm{N}$, even at the massive rates that produced maximum yields, only lasted 2 or 3 years. Slightly greater production was achieved by applying $\mathrm{N}$ every ycar, but $\mathrm{N}$ recoveries of only 10 to $15 \%$ are not economical. Based on the results of this study, we would recommend against applying massive amounts of $\mathrm{N}$ to grass since large proportions are either lost or tied up in the biomass.

Where no fertilizer was applied, the generally larger values for yields and $\mathrm{N}$ uptake during the first 2 years may have been the result of cultivation of the soil before seeding. This operation would encourage the release of some $\mathbf{N}$ through mineralization of the soil organic matter. This, in turn, would stimulate growth and allow the grasses to take advantage of the available moisture. In the first 2 years, low moisture deficit because of high rainfall (Table 1) would also have encouraged greater growth. However, after the first 2 years, IWG and WWG took up two to five times as much $\mathrm{N}$ as the other five grasses. Either $\mathrm{N}$ was still available but five of the grasses could not use it or most of the mineralizable $\mathrm{N}$ was used up in the first 2 years and these two grasses supported some fixation of $\mathrm{N}$ (Dobereiner 1974) to satisfy their needs. This aspect of $\mathrm{N}$ nutrition of grasses is worth some detailed investigation.

\section{Literature Cited}

Association of Official Agricultural Chemists. 1950. Methods of Analysis, 7 th ed. AOAC, Washington, D.C. $910 \mathrm{p}$.

Dobereiner, J. 1974. Nitrogen-fixing bacteria in the rhizosphere. In: The Biology of Nitrogen Fixation. Ed. A. Quispel. Front. Biol. 33:86-120.

Heinricks, D.H., and K.W. Clark. 1961. Clipping frequency and fertilizer effects on productivity and longevity of five grasses. Can. J. Plant Sci. 41: 97-108.

Kilcher, M. 1958. Fertilizer effects on hay production of three cultivated grasses in southern Saskatchewan. J. Range Manage. 11:231-234.

Lorenz, R.J., and G.A. Rogler. 1962. A comparison of methods of renovating old stands of crested wheatgrass. J. Range Manage. 15: 215-219.

Lutwick, L.E., A.D. Smith, and A. Johnston. 1965. Fertilizer experiments on native rangelands using increasing-rate spreader. J. Range Manage. 18: 136-139.

Mason, J.L., and J.E. Miltimore. 1972. Ten year yield response of beardless wheatgrass from a single nitrogen application. J. Range Manage. 25: 269-272.

Seamands, W.J., and R. Lang. 1960. Nitrogen fertilization of crested wheatgrass in southeastern Wyoming. Univ. Wyoming Agr. Exp. Sta., Bull. 364. $16 \mathrm{p}$.

Smika, D.E., H.J. Haas, and G.A. Rogler. 1960. Yield, quality, and fertililizer recovery of crested wheatgrass, bromegrass, and Russian wildrye as influenced by fertilization. J. Range Manage. 13: 243-246.

Sneva, F.S. 1973. Crested wheatgrass response to nitrogen and clipping. J. Range Manage. 26: 47-50. 